\title{
Penerapan Metode Peer Tutoring (Tutor Sebaya) untuk Meningkatkan Prestasi Belajar Siswa pada Pembelajaran Informatika Materi Aplikasi Pengolah Kata di Kelas X IPS 1 SMAN 4 Kota Bima Semester I Tahun Pelajaran 2020/2021
}

\author{
Nurdiyanah \\ SMA Negeri 4 Kota Bima, Kota Bima, Indonesia \\ *Coresponding Author : nurdiyanah0112@gmail.com \\ Dikirim: 19-08-2021; Direvisi: 24-10-2021; Diterima: 25-10-2021
}

\begin{abstract}
Abstrak: Hasil penelitian pra-siklus yang telah dilakukan peneliti, hasilnya bahwa terdapat $20 \%$ siswa yang aktivitasnya tinggi $30 \%$ aktivitasnya sedang dan $50 \%$ siswa aktivitasnya rendah. Hal ini ditunjukkan dengan rendahnya rata-rata nilai formatif tes siswa yakni 64.00 dengan ketuntasan klasikal $68.00 \%$, capaian ini juga dibawah indikator kinerja yang ditentukan rata-rata 70.00 dengan ketuntasan klasikal $83.00 \%$. Mengacu pada latar belakang masalah, identifikasi masalah dan analisis masalah diatas, maka masalah dirumuskan sebagai berikut: "Bagaimanakah cara menerapkan metode peer tutoring (tutor sebaya) untuk meningkatkan prestasi belajar siswa pada pembelajaran Informatika materi aplikasi pengolah kata di kelas X IPS 1 SMAN 4 Kota Bima semester I tahun pelajaran 2020/2021?". Tujuan Perbaikan : 1. Meningkatkan prestasi belajar siswa pada pembelajaran Informatika materi aplikasi pengolah kata semester I kelas X IPS 1 SMAN 4 Kota Bima tahun pelajaran 2020/2021. 2. Meningkatkan kinerja guru khususnya dalam pelaksanaan pembelajaran berkaitan dengan penggunaan metode peer tutoring (tutor sebaya). Penelitian Tindaka Kelas (PTK) ini dilakukan dalam dua siklus. Subyek penelitian ini adalah siswa-siswi kelas X IPS 1 SMAN 4 Kota Bima. Perbaikan dilaksanakan dalam 2 (dua) siklus. Siklus I dari tanggal 21 Agustus 2020 sampai dengan tanggal 29 Agustus 2020 dan siklus II dilaksanakan tanggal 03 September 2020 sampai dengan 11 September 2020. Yang menjadi subyek penelitian ini adalah siswa kelas X IPS 1 SMAN 4 Kota Bima. Jumlah siswa kelas X IPS 1 yakni 30, terdiri dari 14 orang laki-laki dan 16 orang perempuan. Teknik pengumpulan data meliputi pengamatan, dokumen dan tes. Peningkatan prestasi belajar siswa ini dapat dibandingkan dari hasil tes pra-perbaikan. Hasil pos tes siklus I rata-rata $68.12(+4.12)$, persentase ketuntasan $73.00 \%(+5.00)$. Dari sisi prestasi belajar siklus I (pertama) belum berhasil. Sedangkan dalam APKG I $\geq 89.45$ dan APKG II $\geq 88.45$ tetapi masih terdapat 7 deskriptor yang sebagian dilaksanakan (sebagian terpenuhi) dan 4 deskriptor seluruhnya dilaksanakan (seluruhnya terpenuhi). Dengan demikian dari sisi kinerja guru siklus I belum mencapai indikator kinerja yang ditetapkan yakni APKG I dan APKG II $\geq 90.00 \%$. Hasil pos tes siklus II rata-rata $77.00 \%(+8.88)$. Persentase ketuntasan $85.00 \%(+12.00 \%)$. Persentase ini telah memenuhi indikator kinerja yakni $\geq 83 \%$. Dengan demikian pada siklus II ini telah berhasil mencapai indikator yang ditetapkan yakni rata-rata $\geq 70$ dan persentase ketuntasan $\geq 83 \%$. Dari sisi prestasi belajar siklus II (kedua) telah berhasil. Dalam APKG I $\geq 91.00(+1.55)$ dan APKG II $\geq 90.77(+2.32)$. Dengan perbaikan proses pembelajaran berhasil memenuhi indikator kinerja yang ditetapkan yakni APKG I dan APKG II $\geq 90.00 \%$. Peningkatkan Prestasi belajar siswa, disebabkan oleh peningkatan aktivitas, interaksi guru dan siswa dalam proses pembelajaran di kelas dengan penerapan metode peer tutoring (tutor sebaya) yang dilaksanakan guru, sesuai dengan nilai kinerja guru. Dengan demikian setelah pelaksanaan perbaikan pembelajaran sampai siklus II, telah mencapai indikator kinerja yang ditetapkan, dan penelitian dianggap telah berhasil.
\end{abstract}

Kata Kunci: Prestasi belajar; Kinerja guru; metode peer tutoring 


\begin{abstract}
The results of pre-cycle research that has been carried out by researchers, the result is that there are $20 \%$ of students whose activity is high, $30 \%$ of activity is moderate and $50 \%$ of students whose activity is low. This is indicated by the low average formative test scores of students, namely 64.00 with classical completeness of $68.00 \%$, this achievement is also below the performance indicator determined by an average of 70.00 with classical completeness of $83.00 \%$. Referring to the background of the problem, problem identification and problem analysis above, the problem is formulated as follows: "How to apply the peer tutoring method (peer tutors) to improve student achievement in learning Informatics word processing application materials in class X IPS 1 SMAN 4 Kota Bima in the first semester of the 2020/2021 school year?". Improvement Objectives: 1. Improve student learning achievement in learning Informatics word processing application material in the first semester of class X IPS 1 SMAN 4 Bima City for the 2020/2021 school year. 2. Improving teacher performance, especially in the implementation of learning related to the use of peer tutoring methods (peer tutors). This Classroom Action Research (CAR) was conducted in two cycles. The subjects of this study were students of class X IPS 1 SMAN 4 Bima City. Repairs are carried out in 2 (two) cycles. Cycle I from August 21, 2020 to August 29, 2020 and cycle II was held from September 3, 2020 to September 11, 2020. The subjects of this study were students of class X IPS 1 SMAN 4 Kota Bima. The number of students in class X IPS 1 is 30, consisting of 14 boys and 16 girls. Data collection techniques include observations, documents and tests. This increase in student achievement can be compared from the results of the pre-improvement test. The results of the post-test cycle I averaged $68.12(+4.12)$, the percentage of completeness was $73.00 \%(+5.00)$. In terms of learning achievement, the first (first) cycle has not been successful. Meanwhile, in APKG I 89.45 and APKG II 88.45, there are still 7 descriptors which are partially implemented (partially fulfilled) and 4 descriptors are fully implemented (fully fulfilled). Thus, in terms of teacher performance in cycle I, the performance indicators have not yet reached the set performance indicators, namely APKG I and APKG II 90.00\%. The results of post-test cycle II averaged $77.00 \%$ (+8.88). Completeness percentage $85.00 \%(+12.00 \%)$. This percentage has met the performance indicators, namely $83 \%$. Thus, in the second cycle, it has succeeded in achieving the specified indicators, namely an average of 70 and a percentage of completeness $83 \%$. In terms of learning achievement, cycle II (second) has been successful. In APKG I $91.00(+1.55)$ and APKG II $90.77(+2.32)$. By improving the learning process, the performance indicators have been met, namely APKG I and APKG II 90.00\%. Improving student learning achievement, caused by increased activity, interaction of teachers and students in the learning process in the classroom with the application of the peer tutoring method (peer tutoring) carried out by the teacher, in accordance with the teacher's performance value. Thus, after the implementation of learning improvements up to cycle II, the performance indicators have been achieved, and the research is considered successful.
\end{abstract}

Keywords: learning achievement; Teacher performance; peer tutoring method

\title{
PENDAHULUAN
}

Lampiran Peraturan Menteri Pendidikan Dan Kebudayaan Nomor 22 Tahun 2016 Tentang Standar Proses Pendidikan Dasar Dan Menengah menjelaskan prinsip pembelajaran yang digunakan: 1 . dari peserta didik diberi tahu menuju peserta didik mencari tahu; 2. dari guru sebagai satu-satunya sumber belajar menjadi belajar berbasis aneka sumber belajar; 3. dari pendekatan tekstual menuju proses sebagai penguatan penggunaan pendekatan ilmiah; 4. dari pembelajaran berbasis konten menuju pembelajaran berbasis kompetensi; 5. dari pembelajaran parsial menuju pembelajaran terpadu; 6. dari pembelajaran yang menekankan jawaban tunggal menuju pembelajaran dengan jawaban yang kebenarannya multi dimensi; 7 . dari 
pembelajaran verbalisme menuju keterampilan aplikatif; 8. peningkatan dan keseimbangan antara keterampilan fisikal (hardskills) dan keterampilan mental (softskills); 9. pembelajaran yang mengutamakan pembudayaan dan pemberdayaan peserta didik sebagai pembelajar sepanjang hayat; 10 . pembelajaran yang menerapkan nilai-nilai dengan memberi keteladanan (ing ngarso sung tulodo), membangun kemauan (ing madyo mangun karso), dan mengembangkan kreativitas peserta didik dalam proses pembelajaran (tut wuri handayani); 11. pembelajaran yang berlangsung di rumah di sekolah, dan di masyarakat; 12. pembelajaran yang menerapkan prinsip bahwa siapa saja adalah guru, siapa saja adalah peserta didik, dan di mana saja adalah kelas; 13. Pemanfaatan teknologi informasi dan komunikasi untuk meningkatkan efisiensi dan efektivitas pembelajaran; dan 14. Pengakuan atas perbedaan individual dan latar belakang budaya peserta didik.

Pada pra siklus di Kelas X IPS 1 pada materi aplikasi pengolah kata, dalam praktek pembelajaran peneliti belum menerapkan seluruh prinsip pembelajaran yanng diatur dalam Standar Proses. Terdapat 6 prinsip yang belum optimal diterapkan peneliti yakni prisip ke-1, dari peserta didik diberi tahu menuju peserta didik mencari tahu. Dalam hal ini proses pembelajaran peneliti sebagai guru masih dominan memberi tahu siswa. Demikian juga prinsip ke-2, dari guru sebagai satusatunya sumber belajar menjadi belajar berbasis aneka sumber belajar. Dalam prakteknya peneliti sebagai guru masih belum menggunakan aneka sumber belajar. Prinsip ke-7, dari pembelajaran verbalisme menuju keterampilan aplikatif, peneliti juga masih dominan verbalisme. Prinsip ke-9, pembelajaran yang mengutamakan pembudayaan dan pemberdayaan peserta didik sebagai pembelajar sepanjang hayat, belum optimal dilaksanakan. Dan prinsip ke-12, pembelajaran yang menerapkan prinsip bahwa siapa saja adalah guru, siapa saja adalah peserta didik, dan di mana saja adalah kelas. Dalam hal ini peneliti masih belum memperlakukan siapa saja adalah guru, termasuk peserta didik, peneliti masih beranggapan peserta didik tetap siswa dan peneliti adalah gurunya.

Dari kurangnya peneliti memperhatikan prinsip pembelajaran tersebut di SMAN 4 Kota Bima kelas di X IPS 1 untuk pembelajaran Informatika materi aplikasi pengolah kata, menjadikan pembelajaran menjadi pasif dan aktivitas belajar rendah guru sebagai peneliti mendominasi proses pembelajaran.

Sebelum pelaksanaan pembelajaran peneliti menggunakan ceramah dikombinasikan dengan metode tanya jawab. Hasilnya bahwa terdapat $20 \%$ siswa yang aktivitasnya tinggi $30 \%$ aktivitasnya sedang dan 50\% siswa aktivitasnya rendah. Siswa yang aktivitas belajarnya tinggi memang dalam kesehairannya siswasiswa tersebut aktivitasnya tinggi. Kinerja guru, dengan menggunakan instrumen kinerja guru yang diukur dengan APKG I dan APKG II rendah. Nilai APKG I, untuk perencanaan pembelajaran 89.00 dan APKG II, untuk pelaksanaan pembelajaran 88.00. Capaian ini dibawah indikator kinerja yang ditetapkan yakni APKG I, untuk perencanaan pembelajaran $\geq 90.00$ dan APKG II, untuk pelaksanaan pembelajaran $\geq 90.00$. Prestasi belajar siswapun rendah, hal ini ditunjukkan dengan rendahnya ratarata nilai formatif tes siswa yakni 64.00, dengan ketuntasan klasikal 68.00\%. Capaian ini juga dibawah indikator kinerja yang ditentukan rata-rata $\geq 70.00$ adalah ketuntasan klasikal $\geq 83.00 \%$.

Mengidentifikasi masalah, menjadi langkah awal peneliti sebelum mencari solusi atas permasalahan tersebut. Adapun permasalahan pembelajaran sebelum 
kegiatan perbaikan adalah sebagai berikut: 1) Penggunaan ceramah dan metode tanya jawab konvensional tidak efektif; 2) Aktivitas belajar siswa rendah; 3) Prestasi belajar siswa rendah; dan 4) Prinsip-prinsip belajar yang efektif tidak terlaksana.

Dari permasalahan yang berhasil diidentifikasi diatas, dua permasalahan utama yang perlu dicari dan ditemukan solusinya yakni masalah rendahnya aktivitas belajar siswa rendah dan prestasi belajar siswa rendah. Pada prinsip ke-12, pembelajaran yang menerapkan prinsip bahwa siapa saja adalah guru, siapa saja adalah peserta didik, dan di mana saja adalah kelas.Hasil kajian referensi dan diskusi dengan teman sejawat, peneliti memilih penerapan metode peer tutoring (tutor sebaya). Menurut Suharsimi Arikunto adakalanya seorang siswa lebih mudah menerima keterangan yang diberikan oleh kawan sebangku atau kawan yang lain karena tidak adanya rasa enggan atau malu untuk bertanya, guru dapat meminta bantuan kepada anak-anak yang menerangkan kepada kawan-kawannya. Pelaksanaan ini disebut peer tutoring (tutor sebaya) karena mempunyai usia yang hampir sebaya.

Penerapan metode peer tutoring (tutor sebaya) aktivitas pembelajaran tidak lagi didominasi guru melaikan merata pada seluruh siswa, dan guru bukan lagi satusatunya sumber belajar, sekaligus menerapkan semua adalah guru, semua adalah siswa. Dengan demikian aktivitas belajar siswa meningkat dan akan berdampak pada peningkatan prestasi belajar siswa.

\section{KAJIAN TEORI}

\section{Prestasi belajar}

Belajar merupakan suatu proses perubahan tingkah laku sebagai hasil interaksi individu dengan lingkungannya dalam memenuhi kebutuhan hidupnya. Menurut Slameto (2010: 2) "belajar ialah suatu proses usaha yang dilakukan seseorang untuk memperoleh suatu perubahan tingkah laku yang baru secara keseluruhan, sebagai hasil pengalamannya sendiri dalam interaksi dengan lingkungannya".

Menurut Sugihartono (2007: 74) "belajar merupakan suatu proses memperoleh pengetahuan dan pengalaman dalam wujud perubahan tingkah laku dan kemampuan bereaksi yang relatif permanen atau menetap karena adanya interaksi individu dengan lingkungannya".

Menurut Ngalim (2006: 102) "belajar adalah suatu proses yang menimbulkan terjadinya suatu perubahan atau pembaharuan dalam tingkah laku dan atau kecakapan". Wina (2009: 112) "belajar adalah proses mental yang terjadi di dalam diri seseorang, sehingga menyebabkan munculnya perubahan prilaku. Aktivitas mental itu terjadi karena adanya interaksi individu dengan lingkungan yang disadari".

Prestasi belajar menurut Winkel yang dikutip Noor Komari Pratiwi (2015:81) merupakan "bukti keberhasilan yang telah dicapai oleh seseorang. Dengan demikian, prestasi belajar merupakan hasil maksimum yang dicapai oleh seseorang setelah melakukan usaha-usaha belajar".

Menurut Siti Maesaroh (2013:11) menerangkan bahwa "prestasi belajar merupakan hasil daripada aktivitas belajar atau hasil dari usaha, latihan dan pengalaman yang dilakukan oleh seseorang, dimana prestasi tersebut tidak akan lepas dari pengaruh faktor luar diri peserta didik". 


\section{Metode Peer tutoring (Tutor Sebaya)}

Peer tutoring (Tutor Sebaya) merupakan salah satu metode pembelajaran yang berbasis active learning. Beberapa pakar meyakini bahwa suatu subjek dapat dikatakan benar-benar dikuasai hanya jika si pembelajar mampu mengajarkannya kepada orang lain. Mengajar teman memberikan kesempatan kepada murid-murid untuk mempelajari sesuatu dengan sebaik-baiknya dan, pada saat yang bersamaan, menjadi sumber belajar bagi satu sama lain. Menurut Siberrnen (Siberrnen, 2013) Pembelajaran peer teaching merupakan cara yang efektif untuk menghasilkan kemampuan mengajar teman sebaya.

Menurut Suharsimi Arikunto (1992) adakalanya seorang siswa lebih mudah menerima keterangan yang diberikan oleh kawan sebangku atau kawan yang lain karena tidak adanya rasa enggan atau malu untuk bertanya, guru dapat meminta bantuan kepada anak-anak yang menerangkan kepada kawan-kawannya. Pelaksanaan ini disebut Peer tutoring (Tutor Sebaya) karena mempunyai usia yang hampir sebaya.

\section{Langkah - Langkah Peer tutoring}

Menurut Hisyam Zaini langkah-langkah pelaksanaan peer tutoring adalah sebagai berikut :

1) Bagi siswa menjadi kelompok-kelompok kecil sebanyak segmen materi yang akan disampaikan.

2) Masing-masing kelompok kecil diberi tugas untuk mempelajari satu topik materi, kemudian mengajarkannya kepada kelompok lain. Topik-topik yang diberikan harus yang saling berhubungan.

3) Minta setiap kelompok menyiapkan strategi untuk menyampaikan materi kepada teman-teman sekelas. Sarankan kepada mereka untuk tidak menggunakan metode ceramah atau seperti membaca laporan.

4) Buat beberapa saran seperti:

a) Menggunakan alat bantu visual

b) Menyiapkan media pengajaran yang diperlukan

c) Menggunakan contoh-contoh yang relevan

d) Melibatkan siswa lain dalam proses pembelajaran melalui diskusi, permainan, quis, studi kasus dan lainnya.

e) Memberi kesempatan kepada yang lain untuk bertanya.

5) Beri mereka waktu yang cukup untuk untuk persiapan, baik didalam maupun diluar kelas.

6) Setiap kelompok menyampaikan materi sesuai tugas yang telah diberikan.

7) Setelah semua kelompok melaksanakan tugas, beri kesimpulan dan klarifikasi sekiranya ada yang perlu diluruskan dari pemahaman siswa. (Hisyam Zaini, dkk, 2012; Amiruddin \& Jannah, 2021).

\section{Syarat-Syarat Menjadi Tutor}

Tidak semua siswa dapat menjadi tutor bagi teman-teman sebayanya, maka oleh sebab itu ada beberapa kriteria yang menjadi syarat untuk menjadi tutor bagi siswa. Menurut Sawali (Sawali, 2007) Kriteria menjadi tutor adalah sebagai berikut :

1) Memiliki kemampuan akademis di atas rata-rata siswa satu kelas.

2) Mampu menjalin kerja sama dengan sesama siswa 
3) Memiliki motivasi tinggi untuk meraih prestasi akademis yang baik.

4) Memiliki sikap toleransi, tenggang rasa, dan ramah dengan sesama.

5) Memiliki motivasi tinggi untuk menjadikan kelompok diskusinya sebagai yang terbaik.

6) Bersikap rendah hati, pemberani, dan bertanggung jawab, suka membantu sesamanya yang mengalami kesulitan.

\section{Pembelajaran informatik di SMA}

Dirangkum dari Buku Pedoman Implementasi muatan/ Mata Pelajaran Informatika Kurikulum 2013 Jenjang Pendidikan Dasar dan Menengah (Kementerian Pendidikan Dan Kebudayaan Badan Penelitian Dan Pengembangan Pusat Kurikulum Dan Pembelajaran, 2019) menjelaskan:

Kurikulum 2013 yang diberlakukan mulai tahun ajaran 2013/2014 dikembangkan dengan memerhatikan faktor-faktor yang bersifat internal dan eksternal. Faktor yang bersifat internal terkait dengan aspek teknis pengembangan kurikulum, sedangkan faktor eksternal antara lain terkait kebijakan pemerintah yang ditetapkan melalui berbagai produk hukum seperti Peraturan Pemerintah, Keputusan Presiden, Peraturan Menteri, dan peraturan di bawahnya. Faktor eksternal lainnya adalah perubahan-perubahan yang terjadi di masyarakat dalam berbagai aspek kehidupan sosial, budaya, ekonomi, ilmu pengetahuan, teknologi, politik, dan hubungan antar bangsa yang semakin terbuka sebagai akibat globalisasi dan perkembangan pesat teknologi informasi dan komunikasi (TIK).

Teknologi Informasi dan Komunikasi pada Kurikulum 2013 dimanfaatkan sebagai alat pembelajaran (ICT for learning) yang terintegrasi pada semua mata pelajaran karena pada hakikatnya, saat ini semua kegiatan kehidupan termasuk pembelajaran, berbasis TIK. Untuk mewujudkannya warga sekolah seyogyanya memahami dan menerapkan TIK dalam pelaksanaan kegiatan di sekolah. Oleh karena itu, Menteri Pendidikan dan Kebudayaan Republik Indonesia telah mengatur peran guru TIK sebagaimana tertuang dalam Peraturan Menteri Pendidikan dan Kebudayaan Republik Indonesia Nomor 45 Tahun 2015 tentang Perubahan Atas Peraturan Menteri Pendidikan dan Kebudayaan Republik Indonesia Nomor 68 Tahun 2014 tentang Peran Guru Teknologi Informasi dan Komunikasi dan Guru Keterampilan Komputer dan Pengelolaan Informasi dalam Implementasi Kurikulum 2013, yaitu membimbing peserta didik untuk mendukung kelancaran proses pembelajaran, memberikan layanan/fasilitasi kepada sesama guru untuk persiapan, pelaksanaan, dan penilaian pembelajaran dan memberikan layanan/fasilitasi kepada tenaga kependidikan untuk mengembangkan sistem manajemen sekolah berbasis TIK.

Dewasa ini, pemanfaatan TIK sebagai alat pembelajaran dalam dunia pendidikan tidaklah cukup, karena saat ini dunia global telah memasuki era revolusi industri generasi keempat atau Revolusi Industri 4.0 (Industry Revolution 4.0/IR4.0) yang tidak dapat dihindari oleh bangsa Indonesia. IR4.0 menghadirkan sistem cyberphysical, dimana industri bahkan kehidupan sehari-hari mulai bersentuhan dengan dunia virtual yang berbentuk komunikasi manusia dengan mesin yang ditandai dengan kemunculan komputer super, mobil otonom, robot pintar, pemanfaatan Internet of Things (IoT), sampai dengan rekayasa genetika, dan perkembangan neurotechnology. Era ini menghadirkan teknologi disruptif (disruptive technology) yang menggantikan peran manusia. Mengacu pada_manusia dalam bermasyarakat 
sudah memasuki era Society 5.0 dimana masyarakat hidup di dunia nyata dan sekaligus di dunia digital.

Untuk mengikuti perkembangan tersebut di atas, sistem pendidikan Indonesia perlu memberikan Informatika sebagai dasar-dasar pengetahuan dan kompetensi yang dapat membentuk manusia Indonesia menjadi insan yang cerdas dan punya daya saing di kawasan regional maupun global. Beberapa pemikiran yang melandasi pentingnya Informatika diajarkan kepada peserta didik antara lain sebagai berikut.

1. Di dunia digital modern yang dipenuhi dengan komputasi dan perangkat komputer, seseorang hendaknya bukan hanya pengguna di dunia yang tak dipahaminya, tetapi sebaliknya juga berperan serta secara aktif dan menguasai konsep dasar informatika.

2. Pemahaman konsep Informatika yang baik akan membuat peserta didik sejak usia dini dapat memanfaatkan sistem komputer dengan baik dan dapat memberikan solusi persoalan pada saat suatu sistem tak berjalan sebagaimana mestinya.

3. Warga dunia digital yang mampu berpikir komputasional akan mampu untuk memahami secara rasional tentang isu-isu terkait, seperti: hak kekayaan intelektual perangkat lunak, pencurian identitas, rekayasa genetika, kejahatan cyber, dan sebagainya.

4. Adanya standar dan framework kurikulum Informatika yang sudah dirilis dan diimplementasikan oleh negara maju, antara lain yang dirilis oleh Association for Computing Machinery (ACM), Computer Science Teacher Association (CSTA), dan lembaga nirlaba (code.org) maupun industri.

Pada bulan Desember tahun 2018, Kementerian Pendidikan dan Kebudayaan telah mengakomodasi kebijakan diselenggarakannya Informatika sebagai muatan pembelajaran pada Sekolah Dasar/Madrasah Ibtidaiyah (SD/MI) dan sebagai mata pelajaran (mapel) Informatika pada Sekolah Menengah Pertama/Madrasah Tsanawiyah (SMP/MTs) dan Sekolah Menengah Atas/Madrasah Aliyah (SMA/MA).

\section{METODE PENELITIAN}

\section{Lokasi Perbaikan}

Perbaikan ini dilakukan di kelas X IPS 1 SMAN 4 Kota Bima.

\section{Waktu Perbaikan}

Perbaikan dilaksanakan dalam 2 (dua) siklus. Siklus I dari tanggal 21 Agustus 2020 sampai dengan tanggal 29 Agustus 2020 dan siklus II dilaksanakan tanggal 03 September 2020 sampai dengan 11 September 2020.

\section{Mata Pelajaran} semester I.

Mata pelajaran yang dilakukan perbaikan adalah Informatika kelas X IPS 1

\section{Subyek Perbaikan}

Yang menjadi subyek penelitian ini adalah siswa kelas X IPS 1 SMAN 4 Kota Bima. Jumlah siswa kelas X IPS 1 yakni 30, terdiri dari 14 orang laki-laki dan 16 orang perempuan. Secara umum karakteristik adalah siswa dengan intake (kemampuan dasar) sedang dan dari sisi latar belakang pendidikan orang tua 
sebagian besar orang tua berpendidikan SMP kebawah. Motivasi belajar siswa ratarata sedang.

\section{Desain Prosedur Perbaikan Pembelajaran}

\section{Gambaran Umum Penelitian}

a) Sumber data: sumber data penelitian ini adalah seluruh siswa kelas X IPS 1 SMAN 4 Kota Bima.

b) Jenis data:

(1.) Data kualitatif terdiri dari:

- Teacher's note (Rancangan Pembelajaran)

- Data hasil observasi pelaksanaan pembelajaran dan activitas siswa.

- Jurnal tim peneliti

(2) Data Kuantitatif

1) Nilai pos tes

2) Teknik Pengambilan data

a. Data kualitatif diambil dari teacher's note (rencana pembelajaran) yang dibuat peneliti.

b. Data tentang refleksi diri diambil dari jurnal yang dibuat oleh peneliti.

c. Data kuantitatif diambil dari skor nilai tes siswa.

\section{Indikator Kinerja}

a) Prestasi belajar siswa, rata-rata nilai post test untuk pembelajaran Informatika $\geq 70$.

b) Prosentase ketuntasan belajar siswa $\geq 83 \%$

c) Kinerja Guru, APKG I untuk perencanaan pembelajaran $\geq 90.00$.

d) Kinerja Guru, APKG II untuk pelaksanaan pembelajaran $\geq 90.00$

\section{Intrumen Penelitian}

a. Instrumen penelitian berupa pos tes.

b. Lembar observasi kinerja guru.

\section{Deskripsi Per-siklus/Desain Perbaikan}

Perbaikan pembelajaran ini merupakan Penelitian penelitian tindakan yang dilakukan untuk meningkatkan prestasi belajar siswa pada pembelajaran Informatika materi aplikasi pengolah kata. Tindakan yang digunakan adalah dengan menggunakan metode peer tutoring (tutor sebaya). Proses tindakan ini melalui tiga tahap secara berdaur ulang (sebagai siklus) mulai dari (1) tahap perencanaan, (2) tahap pelaksanaan tindakan dan observasi, dan (3) tahap evaluasi dan refleksi. Dalam perbaikan pembelajaran ini melalui 2 (dua) siklus.

\section{Siklus I (pertama)}

a) Tahap Perencanaan

Kegiatan yang dilakukan pada tahap ini dilakukan secara kolaboratif antar guru dan peneliti dengan mengadakan kegiatan sebagai berikut:

1) Mengamati metode peer tutoring (tutor sebaya) yang digunakan dalam pembelajaran Informatika materi aplikasi pengolah kata.

2) Mengidentifikasi faktor-faktor hambatan yang ditemui guru dalam pembelajaran Informatika materi aplikasi pengolah kata. 
3) Merumuskan alternatif tindakan yang akan dilaksanakan dalam pembelajaran sebagai upaya untuk meningkatkan prestasi belajar siswa pada pembelajaran Informatika materi aplikasi pengolah kata dalam hal ini dengan menggunakan metode peer tutoring (tutor sebaya).

4) Menyusun Rencana Pelaksanaan Pembelajaran (RPP) Informatika semester I kelas X IPS 1 dengan menggunakan metode peer tutoring (tutor sebaya). (terlampir)

b) Tahap Pelaksanaan sejawat):

Pada tahap tindakan dan observasi ini, peneliti dan observer (teman

1. Memberikan pengarahan, motivasi, dan stimulus pada peneliti (guru) dalam melaksanakan perannya berdasarkan rencana.

2. Dengan menggunakan instrumen pengumpulan data, observer berusaha melakukan pemantauan terhadap pelaksanaan tindakan pembelajaran, kendala yang dihadapi serta kesempatan dan peluang yang berkaitan dengan penggunaan metode peer tutoring (tutor sebaya).

3. Sedangkan peran guru (peneliti) adalah sebagai pelaksana semua tindakan yang telah direncanakan, kemudian bersama-sama dengan observer melakukan observasi terhadap segala tindakan.

c) Tahap Evaluasi dan Refleksi

Pada tahap ini peneliti (sekaligus menjadi guru) dan observer mendiskusikan hasil pengamatan yang telah dilaksanakan. Hal-hal yang dibahas adalah :

1) Analisis dan tindakan yang dilakukan

2) Mengulas dan merencanakan perbedaan rencana dengan pelaksanaan tindakan yang telah dilaksanakan

3) Melakukan intervensi, pemaknaan, dan penyimpulan data yang telah diperoleh.

Melakukan rencana tindakan berdasarkan hasil evaluasi terhadap pelaksanaan tindakan pada siklus I (jika diperlukan).

d) Instrumen Penelitian

(1) Instrumen yang digunakan untuk menjaring data penelitian ini adalah catatan harian guru pada proses belajar mengajar, lembar observasi dan prestasi belajar siswa belajar siswa berupa Bentuk instrumen berupa pos tes.

e) Analisis Data

Analisis data dalam penelitian tindakan masuk pada tahap refleksi. Pada tahap refleksi, peneliti dan observer mendiskusikan hasil pengamatan tindakan yang telah dilakukan. Hal yang dilakukan adalah (1) menganalisis tentang tindakan yang dilakukan, (2) mengulas dan menjelaskan perbedaan rencana dengan pelaksanaan tindakan yang telah dilaksanakan, (3) melakukan intervensi, pemaknaan, dan penyimpulan data yang telah diperoleh, dan (4) melakukan perencanaan berdasarkan hasil evaluasi terhadap pelaksanaan tindakan siklus I (jika diperlukan).

\section{Siklus II (kedua)}

Langkah-langkah sisklus II tidak jauh berbeda dengan siklus I. Yang membedakan adalah pelaksanaannya, dimana pelaksanaan perbaikan langkahlangkahnya mengacu pada hasil refleksi siklus I. 


\section{Teknik dan Alat Pengumpulan Data}

Teknik pengumpulan data kualitatif diambil melalui dokumentasi dan tes. Sedangkan pengumpulan data kuantitatif diambil melalui tes. Penjelasan tehnik pengumpulan data sebagai berikut :

a) Dokumentasi

Metode dokumentasi yaitu mencari data mengenai hal-hal atau variable yang berupa catatan lapangan, transkip, buku, surat kabar, majalah, prasasti, notulen rapat, agenda, dan sebagainya (Arikunto, 2002).

Studi dokumentasi dilakukan untuk memperkuat data yang di peroleh dalam observasi. Dokumen yang di gunakan dalam penelitian ini berupa LKS dan daftar nilai siswa.

b) Tes

Tes adalah serentetan pertanyaan atau latihan serta alat lain yang digunakan untuk mengukur keterampilan, pengetahuan inteligensi, kemampuan atau bakat yang dimiliki oleh individu atau kelompok (Arikunto, 2002). Tes dapat digunakan untuk mengukur kemampuan dasar dan pencapaian atau prestasi belajar. Tes diberikan kepada siswa untuk mengetahui kemampuan kognitif siswa. Tes ini dikerjakan siswa secara individual setelah mempelajari suatu materi. Tes ini dilaksanakan pada saat proses pembelajaran melalui LKS dan tes akhir pembelajaran pada siklus I, siklus II.

\section{Teknik Analisis Data}

Penelitian ini dikatakan berhasil jika ada perubahan-perubahan menuju arah kebaikan yang berkaitan dengan siswa, guru, suasana proses belajar di kelas dan perangkat pembelajaran. Perubahan yang terjadi dapat diketahui dengan membandingkan hasil sebelum dan sesudah diberi tindakan yang berkaitan dengan prestasi belajar siswa.

a. Penghitungan Prestasi Belajar siswa

Analisis data prestasi belajar menggunakan non tes dengan rubric penilaian sebagai berikut:

b. Menghitung nilai setiap siswa :

$$
\frac{\text { Jml. skor yang diperoleh }}{\text { skor maksimal }} \times 100
$$

c. Menghitung nilai rata-rata kelas menggunakan rumus :

$$
\text { Skor rata-rata kelas }=\frac{\text { jml.skor seluruh siswa }}{\text { jumlah siswa }}
$$

d. Menghitung persentase jumlah siswa yang mencapai KKM dengan menggunakan rumus :

e. Persentase jumlah siswa yang mencapai $\mathrm{KKM}=$

$$
\frac{\text { jml.yang mencapai } K K M}{\text { jml. seluruh siswa }} \times 100 \%
$$

\section{Kinerja Guru}

Menghitung persentase capaian kinerja guru dalam melaksanakan pembelajaran dengan penerapan metode pembelajaran

Persentase capaian kinerja guru $=$ 


$$
\frac{j m l . s k o r \text { capaian pelaksanaan pembelajaran }}{\text { skor maksimal }(15 \times 4=60)} \times 100 \%
$$

\section{Kriteria:}

Tabel 1. Kriteria Kinerja Guru

\begin{tabular}{|c|c|}
\hline Aktivitas $(\%)$ & Kriteria \\
\hline $91-100$ & Sangat Baik \\
\hline $76-90$ & Baik \\
\hline $51-75$ & Cukup baik \\
\hline$\leq 50$ & Kurang baik \\
\hline
\end{tabular}

\section{HASIL DAN PEMBAHASAN}

\section{Deskripsi Data}

\section{Hasil Perbaikan}

\section{a) Perencanaan}

Metode pembelajaran tutor sebaya (peer tutoring) pada dasarnya adalah memberi kesempatan siswa untuk menjadi guru pada sesama temannya. Artinya siswa belajar sambil mengajar. Oleh karena pembelajaran bernuansa pembelajaran maka guru perlu benar-benar memahami karakteristik dalam metode pembelajaran tutor sebaya (peer tutoring) agar pembelajaran yang dilukan berjalan seperti yang direncanakan.

Mempersiapkan fasilitas media pembelajaran yang akan diguanakan siswa merupakan kunci keberhasilan metode pembelajaran tutor sebaya (peer tutoring).

Setelah semua sumber bahan dan media pembelajaran telah siap guru menyusun RPP dengan rambu-rambu metode pembelajaran tutor sebaya (peer tutoring). Dengan memperhatikan dengan cermat karakter metode pembelajaran tutor sebaya (peer tutoring), karakter materi pembelajaran RPP dalan disusun dengan baik dan lengkap.

Adapun hasil post tes prestasi belajar dan kinerja guru dimuat dalam siklus I dan siklus II adalah sebagai berikut:

Tabel 2. Prestasi belajar siswa siklus I dan siklus II

\begin{tabular}{|c|c|c|c|c|c|}
\hline \multicolumn{2}{|c|}{ Pra Siklus } & \multicolumn{2}{c|}{ Siklus I } & \multicolumn{2}{c|}{ Siklus II } \\
\hline $\begin{array}{c}\text { Rata- } \\
\text { Rata }\end{array}$ & $\begin{array}{c}\% \\
\text { Ketercapaian }\end{array}$ & $\begin{array}{c}\text { Rata- } \\
\text { Rata }\end{array}$ & $\begin{array}{c}\% \\
\text { Ketercapaian }\end{array}$ & $\begin{array}{c}\text { Rata- } \\
\text { Rata }\end{array}$ & $\begin{array}{c}\% \\
\text { Ketercapaian }\end{array}$ \\
\hline 64.00 & $68.00 \%$ & 68.12 & $73.00 \%$ & 77.00 & $85.00 \%$ \\
\hline
\end{tabular}

Tabel 3. Nilai Kinerja guru siklus I dan II

\begin{tabular}{|c|c|c|c|c|c|}
\hline \multicolumn{2}{|c|}{ Pra Siklus } & \multicolumn{2}{c|}{ Siklus I } & \multicolumn{2}{c|}{ Siklus II } \\
\hline APKG & APKG & APKG & APKG & APKG & APKG \\
I & II & I & II & I & II \\
\hline 89.00 & 88.00 & 89.45 & 88.45 & 91.00 & 90.77 \\
\hline
\end{tabular}

b) Penerapan Tindakan Siklus I

Penerapan metode pembelajaran tutor sebaya (peer tutoring) mulai muncul ketika pembentukan kelompok dan pembagian tugas kelompok, pembagian sub materi yang akan dejelaskan oleh tiap kelomok pada pembelajaran Informatika. Pada langkah ini terdapat kelompok yang merasa materinya lebih sulit dibanding dengan 
kelomppok lainnya. Dalam hal ini guru meyakinkan siswa dalam kelompok bahwa kelompk tersebut dapat menjelaskan materinya kepada kelompok lain yang penting dalam kerja kelompok mempersiapkan materi dilakukan dengan sungguh-sungguh.

Pada langkah kerja kelompok persiapan materi, secara umum berjalan dengan baik, akan tetapi terdapat satu kelompok yang belum tuntas mempersiapkan materi sampai pada waktu yang ditentukan.

Selanjutnya pada langkah tutor sebaya (peer tutoring) dimana tiap kelompok menjadi guru, kepada siswa, kelompok yang lain secara bergiliran sesuai sub materi yang ditugaskan, terdapat 2 kelompok yang melaksanakan tugasnya dengan sangat baik 2 kelompok cukup dan satu kelomppok kurang.

Secara umum, langkah-langkah yang direncanakan dalam RPP terlaksana tetapi hasilnya belum optimal.

c) Observasi

Kegiatan observasi dilakukan oleh observer mengamati jalannya proses pembelajaran. Dalam observasi ini observer menggunakan lembar observasi dimana dalam format lembar observasi mengacu pada instrumen penilaian kinerja guru kompetensi guru dalam melaksanakan kegiatan pembelajaran yang mendidik. Tiap item diberi skor :

- 0 = tidak ada bukti (tidak terpenuhi)

- $1=$ terpenuhi sebagian

- 2 = terpenuhi seluruhnya

Ketuntasan guru dalam melaksanakan kinerja guru kompetensi guru dalam melaksanakan kegiatan pembelajaran yang mendidik disajikan dalam prosen (\%).

\section{Pembahasan Per Siklus}

\section{Siklus Pertama (I)}

a. Prestasi belajar

Pada pembelajaran Informatika. Hasil pos tes siklus I diatas menunjukkan bahwa prestasi belajar siswa rata-rata 68.12 meskipun nilai rata-rata ini telah mengalami peningkatan dibanding sebelum diadakan perbaikan $(+4.12)$, tetapi nilai ini belum memenuhi indikator kinerja yang ditetapkan yakni rata-rata $\geq 70$. Persentase ketuntasan $73.00 \%$, mengalami peningkatan dibanding sebelum diadakan perbaikan (+5.00). Persentase ini masih dibawah indikator kinerja yakni $\geq 83 \%$. Dari sisi prestasi belajar siklus I (pertama) belum berhasil.

b. Kinerja guru

Pada pembelajaran Informatika. Skor kinerja guru kompetensi guru dalam APKG I, untuk perencanaan pembelajaran $\geq 89.45$ dan APKG II, untuk pelaksanaan pembelajaran $\geq 88.45$ meskipun nilai kinerja guru mengalami peningkatan dibanding sebelum diadakan perbaikan (+0.45) tetapi masih terdapat 7 deskriptor yang sebagian dilaksanakan (sebagian terpenuhi) dan 4 deskriptor seluruhnya dilaksanakan (seluruhnya terpenuhi). Dengan demikian dari sisi kinerja guru siklus I belum mencapai indikator kinerja yang ditetapkan yakni APKG I dan APKG II $\geq 90.00 \%$.

c. Refleksi

Data dan pembahasan diatas menunjukkan bahwa dari komponen Rencana Pembelajaran (RPP) sudah cukup bagus. Belum tercapainya indikator prestasai belajar siswa disebabkan guru belum mampu mengoptimalkan seluruh langkahlangkah yang ditetapkan dalam RPP sebagaimana diuraikan dalam pelaksanaan 
pembelajaran. Perlu perbaikan pada pelaksanaan pembelajaran di kelas khususnya pada hal-hal sebagai berikut:

- Guru perlu dengan jelas memberikan petunjuk, langkah-langkah yang harus dilakukan tiap kelompok dengan penerapan metode peer tutoring (tutor sebaya).

- Guru perlu mengelola kelas dengan efektif khususnya memonitoring kerja kelompok dan memastikan bahwa tiap kelompok dapat melaksanakan tugasnya dengan baik dalam mempersiapkan menyampaikan materi, menjadi tutor kepada teman lainnya.

- Guru perlu memberikan banyak kesempatan kepada peserta didik untuk bertanya, berinteraksi pada saat satu kelompok menjelsakan menjadi tutor kepada kelompok yang lain.

- Guru perlu memastikan seluruh kelompok berkolaborasi dengan baik sehingga anggota kelompok berkontribusi baik dalam menyiapkan materi maupn dalam menjelaskan materi.

- Guru perlu memberikan apresiasi dan menyemangati dengan positif kepada seluruh kelompok yang telah menyelesaikan tugasnya khususnya dalam menjelaskan materi, menjadi tutor kelompok lainnya.

\section{Pembahasan Siklus Kedua (II)}

a. Hasil perbaikan

(1) Perencanaan

Perencanaan siklus II dilakukan dengan mempertimbangkan hasil refleksi siklus I. Fokus perencanaan pada rencana perbaikan pelaksanaan proses pembelajaran.

(2) Penerapan Tindakan

Dalam penerapan Siklus II tindakan guru berupaya memperhatikan hasil refleksi sekaligus menindaklanjutinya. Dari materi pembelajaran tidak mengalami kesulitan, dan tidak mengalami perubahan yang signifikan. Penerapan tindakan terfokus pada aturan main metode peer tutoring (tutor sebaya) yang belum dilaksanakan secara tepat pada siklus sebelumnya. Dengan mengacu pada hasil refleksi, maka secara teknis pelaksanaan pada siklus II berjalan dengan lancar.

- Guru berhasi memberikan petunjuk, langkah-langkah yang harus dilakukan tiap kelompok dengan penerapan metode peer tutoring (tutor sebaya).

- Guru dapat mengelola kelas dengan efektif khususnya memonitoring kerja kelompok dan memastikan bahwa tiap kelompok dapat melaksanakan tugasnya dengan baik dalam mempersiapkan menyampaikan materi, menjadi tutor kepada teman lainnya.

- Guru telah memberikan banyak kesempatan kepada peserta didik untuk bertanya, berinteraksi pada saat satu kelompok menjelsakan menjadi tutor kepada kelompok yang lain.

- Guru berhasil memastikan seluruh kelompok berkolaborasi dengan baik sehingga anggota kelompok berkontribusi baik dalam menyiapkan materi maupn dalam menjelaskan materi.

- Guru telah memberikan apresiasi dan menyemangati dengan positif kepada seluruh kelompok yang telah menyelesaikan tugasnya khususnya dalam menjelaskan materi, menjadi tutor kelompok lainnya. 
(3) Observasi

Dalam kegiatan ini langkah-langkah tidah jauh berbeda dengan yang dilaksanakan pada siklus I. Observer menggunakan lembar observasi kinerja guru untuk mengamati seluruh pelaksanaan proses pembelajaran. Adapun hasilnya dideskripsikan sebagai berikut:

a) Prestasi belajar

Pada pembelajaran Informatika. Hasil pos tes siklus II diatas menunjukkan bahwa prestasi belajar siswa rata-rata $77.00 \%$ nilai rata-rata ini telah mengalami peningkatan dibanding sebelum diadakan perbaikan (+8.88). Persentase ketuntasan $85.00 \%$, mengalami peningkatan dibanding sebelum diadakan perbaikan $(+12.00 \%)$. Persentase ini telah memenuhi indikator kinerja yakni $\geq 83 \%$. Dengan demikian pada siklus II ini telah berhasil mencapai indikator yang ditetapkan yakni rata-rata $\geq 70$ dan persentase ketuntasan $\geq 83 \%$. Dari sisi prestasi belajar siklus II (kedua) telah berhasil.

b) Kinerja guru

Pada pembelajaran Informatika. Skor kinerja guru menunjukkan bahwa skor ketuntasan guru dalam APKG I, untuk perencanaan pembelajaran $\geq 91.00$ mengalami peningkatan dibanding sebelum diadakan perbaikan $(+1.55)$ dan APKG II, untuk pelaksanaan pembelajaran $\geq 90.77$ mengalami peningkatan dibanding sebelum diadakan perbaikan $(+2.32)$. Dengan perbaikan proses pembelajaran berhasil memenuhi indikator kinerja yang ditetapkan yakni APKG I dan APKG II $\geq 90.00 \%$.

(4) Refleksi

Metode pembelajaran tutor sebaya (peer tutoring) dapat berhasil dimana seluruh siswa di kelas tersebut aktif dalam melaksanakan proses pembelajaran sesuai peran masing-masing dalam kelompok. Kunci keberhasilan adalah pada ketrampilan guru daam mengelola kelas khususnya dalam monitoring. Metode pembelajaran tutor sebaya (peer tutoring) ini peran guru sebagai fasilitator menjadi dominan. Pada siklus II guru telah berhasil memenej kelas sehingga para siswa memahami aturan main metode pembelajaran tutor sebaya (peer tutoring) dan mentaati aturan main tersebut, yang pada kahirnya seluruh siswa secara proporsional diberikan hak bicara, hak mengemukakan pendapat, sekaligus melaksanakan kewajibannya sebagai tutor penyaji materi pelajaran yang baik.

Beberapa keunggulan yang muncul dengan menggunakan tutor sebaya (peer tutoring), pada penelitian ini seperti yang dikemukakan Djamarah (Djamarah, 2010) berikut ini:

1) Bagi tutor pekerjaan tutoring akan dapat memperkuat konsep yang sedang dibahas.

2) Bagi tutor merupakan kesempatan untuk melatih diri memegang anggung jawab dalam mengemban suatu tugas dan melatih kesabaran.

3) Mempererat hubungan antar siswa sehingga mempertebal perasaan sosial.

Sampai akhir siklus II ini peneliti telah merasa puas dengan proses dan hasilnya, sehingga kegiatan pembelajaran dengan menerapkan metode pembelajaran tutor sebaya (peer tutoring) tidak perlu dilanjutkan pada siklus berikutnya. 


\section{KESIMPULAN}

Dari hasil pembahasan dapat disimpulkan bahwa: 1) Penerapan metode peer tutoring (tutor sebaya) dapat meningkatkan prestasi belajar siswa pada pembelajaran Informatika materi aplikasi pengolah kata di kelas X IPS 1 SMAN 4 Kota Bima semester I tahun pelajaran 2020/2021; 2) Penerapan metode peer tutoring (tutor sebaya) dapat meningkatkan kinerja guru dalam perencanaan dan pelaksanaan proses pembelajaran.

Saran dan tindak lanjut dari hasil penelitian ini adalah: 1) Disarankan kepada guru-guru untuk dapat menggunakan metode peer tutoring (tutor sebaya) dalam pembelajaran untuk meningkatkan proses dan prestasi belajar siswa baik untuk pembelajaran Informatika maupun pembelajaran lainnya; 2) Disarankan kepada sekolah untuk mendorong terciptanya tradisi meneliti di kalangan guru dan memberikan dukungan terhadap upaya guru dalam rangka megoptimalkan proses dan hasil belajar siswa; dan 3) Menjadikan penelitian sebagai salah satu kreativitas dan inovasi pengembangan Standar Proses baik untuk keperluan Akreditasi Sekolah maupun untuk menngkatkan capaian Rapor Mutu Sekolah.

\section{DAFTAR PUSTAKA}

Arikunto, S. (2002). Prosedur Penelitian Suatu Pendekatan Praktek. Jakarta: Asdi Mahasatya.

Arifin, Zainal. (1990). Evaluasi Instruksional. Bandung : PT. Remaja Rosdakarya.

Amiruddin, M., \& Jannah, U. R. (2021). Pelatihan Bahasa Inggris Bagi Anak Usia Dini di Daerah Terpencil Kecamatan Pademawu Pamekasan. Bima Abdi: Jurnal Pengabdian Masyarakat, 1(1), 18-22.

A.Suhaenah Suparno. (2000). Membangun Kompetensi Belajar.Direktorat Jendral Pendidikan Tinggi Departemen Pendidikan Nasional.

Depdiknas. (2003). Undang-undang RI No.20 tahun 2003.tentang sistem pendidikan nasional.

DePorter, Bobbi \&Mike Hernacki. (2001). Quantum Learning. Membiasakan Belajar Nyaman dan Menyenangkan.Bandung : Penerbit Kaifa.

Hamalik, Umar. (1983). Metodologi Belajar dan Kesulitan-kesulitan Belajar. Jakarta: Tarsito.

Hisyam Zaini dkk. (2012). Strategi Pembelajaran Aktif. Yogyakarta: CTSD

Hurlock, Elizabeth B. (2011). Psikologi Perkembangan : Suatu Pendekatan Sepanjang Rentang Kehidupan. Jakarta : Erlangga.

Kemendikbud. (2016). Permendikbud Nomor 22 Tahun 2016 Tentang Standar Proses Pendidikan Dan Menengah. Jakarta: Kemendikbud.

Kemendikbud. (2013). Permendikbud No.54 tentang Standar Kompetensi Lulusan Pendidikan Dasar dan Menengah. Jakarta: Kementerian Pendidikan dan Kebudayaa 
Maryani dan Syamsudin. (2009). Pengembangan Program Pembelajaran IPS untuk Meningkatkan Kompetensi Keterampilan Sosial. Jurnal. Volume 9 Nomor 1. Halaman 5.

Melvi L Siberrnen. (2013). 101 Strategi Pembelajaran Aktif (Active Learning). terj. Yovita Hardiwati. Jakarta: PT Indeks.

Muhibbin Syah, Psikologi Pendidikan, Bandung, PT Remaja Rosdakarya, (2008).

Mulyatiningsih, E. (2011). Metode Penelitian Terapan Bidang Pendidikan. Yogyakarta: Alfabeta.

Poerwadarminta, W. J. S. (1988). Kamus Umum Bahasa Indonesia. Jakarta: Balai Pustaka.

Permendikbud (2014). Peraturan Menteri Pendidikan dan Kebudayaan No. 103 Tahun 2014 pasal 2 ayat 7 dan 8 tentang Pembelajaran Pada Pendidikan Dasar dan Pendidikan Menengah.

Permendikbud Republik Indonesia Nomor 69 (2013). Tentang Kerangka Dasar dan Struktur Kurikulum Sekolah Menengah Atas/Madrasah Aliyah.

Santrock (2003) John W. Adolescence. Perkembangan Remaja. Edisi Keenam. Jakarta: Erlangga.

Sawali. (2007). Pengajaran dengan Metode Tutor Sebaya. Jakarta: Rajawali Press.

Sergiovanni. (1987). Educational Governance and Administration. New Jersey: Prentice Hall Inc.

Suharsimi Arkunto, Pengelolaan Kelas dan Siswa, Rajawali, Jakarta, (1992), h. 62.

Suharsimi Arkunto (1992). Pengelolaan Kelas dan Siswa. Jakarta: Rajawali

Sumaatmadja, N. (1997). Metodologi Pengajaran Informatika. Jakarta. Bumi Aksara.

Suryabrata Sumadi, Psikologi Pendidikan, (Jakarta : Rajawali, 1980).

Syaiful Bahri Djamarah dan Azwan Zain. (2010). Strategi Belajar Mengajar, Jakarta:Rineka Cipta. 